UDC 378:37.02:37.01/.09

Olena Y. Zhyhadlo

$\mathrm{PhD}$ in Linguistics, Associate Professor, Foreign Languages Department,

Educational and Research Law School, Taras Shevchenko National University of Kyiv, Kyiv, Ukraine

ORCID ID 0000-0002-1605-7242

olena.zhygadlo@gmail.com

\title{
APPLICATION OF DIGITAL GAME-BASED TOOLS FOR FORMATIVE ASSESSMENT AT FOREIGN LANGUAGE LESSONS
}

\begin{abstract}
The research explores the potential of online gamified resources used as means of formative assessment during foreign language lessons in higher education institutions. The use of any game-based tools with certain game elements which can be integrated into conventional or online teaching and learning is considered to be characteristic of game-based approach to teaching and learning. The study established the main elements of educational gamified tools. These elements of game mechanics are capable of triggering such senses and emotions as reward, challenge, achievement, competition and positive emotions. A number of theoretical and empirical research methods have been applied to analyse and prove the benefits of digital interactive tools as effective means of formative assessment of students' progress in mastering a foreign language and an invaluable source for constructive feedback for the development of students' foreign language competence. Three online game-based learning platforms, Kahoot!, Wordwall and Mentimeter, have been selected for analysis. Being compatible with popular video conferencing solutions, these tools proved to be easy to master and suitable for the tasks and purposes of foreign language lessons. The author maintains that activities devised with the help of Wordwall, Kahoot! and Mentimeter can be employed at foreign language lessons to practise vocabulary and grammar, to consolidate the material and reinforce learning, to assess the knowledge of the syllabus vocabulary and grammar, to check comprehension of texts, to revise for tests. The analysis of game mechanics proves that online game-based tools facilitate mastering knowledge and skills by means of influencing students' motivational sphere through creating enjoyable learning environment and providing prompt feedback. Another major advantage of digital gamified resources is supplying the educator with a variety of instruction tools and assessment techniques to meet individual student needs. Detailed reports on student performance in activities available in the toolbar of these platforms offer useful data for analysis and creating an effective teacher feedback aimed at developing students' foreign language competence.
\end{abstract}

Keywords: gamification of learning; teacher feedback; internal and external motivation; foreign language competence; distance learning tools.

\section{INTRODUCTION.}

Statement of the problem. During the Covid-19 pandemic, educators faced new challenges as many traditional techniques and approaches appeared to be inapplicable or simply ineffective when employed in the circumstances of online teaching and learning, which substituted the familiar face-to-face interaction of students with their instructors and peers in classrooms. In Ukraine, the situation of the tightened quarantine introduced in response to the rising levels of coronavirus disease in spring 2020 has significantly accelerated the implementation of online learning and ICTs in secondary and higher education establishments.

On a global scale, however, online tools and platforms have been successfully integrated into classroom setting for years, and distance learning has been constantly improving due to learning opportunities opened by new computer technologies, such as various learning management systems and video conferencing, which makes penetration of information technologies into educational process irrevocable. Back in 2017, Forbes 
magazine named 6 key digital transformation trends impacting education: augmented/virtual/mixed reality, classroom set of devices, redesigned learning spaces, artificial intelligence, personalized learning, gamification [1]. When applied to instruction and assessment, these technologies are aimed at making learning "collaborative and interactive" [ibid.]. The term "gamification" as a dynamic system of practices designed for problem solving and gauging the result in certain fixed conditions which tend to imitate the reality has practically become the buzzword in the last decade due to the growing popularity of gamebased techniques applied in business environment and students' learning.

Increasing digitalization of education in Ukraine is closely related to the availability of game-based learning platforms that can be successfully integrated in remote and hybrid learning environment with the help of portable gadgets. These modern online resources are interactive as well as easy to access and share via a videoconferencing platform, which makes them an invaluable tool during lessons of foreign languages in higher education institutions not only for practicing, but also for effective assessment of the syllabus vocabulary and grammar. The latest trends in education characterized by the soaring importance of digital technologies and tools for personalized learning coupled with constant search of teachers for new approaches and techniques to make their lessons more engaging for students and to improve learning outcomes account for the interest of foreign language (FL) teachers in numerous online game-based tools which can assist them in instruction. Thus, the innovative qualities of online gamified resources lie in increasing motivation and generating data for detailed quantitative and qualitative feedback available to teachers and learners. At the same time, effective integration of gamification tools into FL lessons implies clear understanding of the mechanics of gamified activities for teacher assessment and self-assessment, their benefits and drawbacks for teachers and learners as well as the development of a certain algorithm of interpreting results. In light of the above, the possibilities for assessment of students' learning outcomes at FL lessons offered by online game-based learning resources undoubtedly require thorough investigation.

Analysis of recent research and publications. Due to the growing impact of digitalization on education, the issue of application of ICTs in general and game-based tools in particular to various purposes of teaching and learning has increased its relevance both in international and domestic scholarly literature. There is an ample body of research showing the effect of games on student learning outcomes. J.L. Plass et al. [2] employed the integrated approach to the analysis of learning games describing their design and mechanics from cognitive, motivational, affective and sociocultural perspectives. The research by A. Khan et al., who studied the impact of computer technologies and game-based learning on student engagement in secondary school, proved that gamification learning approaches and digital game-based tools integrated into science lessons "played a vital role in enhancing student engagement and understanding complex learning concepts" [3]. D. Yousef et al. [4] explored the effect of game-based learning on both intrinsic and extrinsic motivation levels of university students and concluded that using games in educational process has a generally beneficial effect on students' motivation and performance not only in the aspect of reinforcing the taught material but also in terms of soft-skills development.

Works of Ukrainian scholars, which explore the issue of gamification and game-based tools in education, focus on basic trends in gamification of formal and informal education [5], benefits of gamified techniques as a powerful source of primary schoolchildren's engagement and motivation to study [6], application of game-based tools to professional training of students of higher pedagogical educational institutions [7]. The potential of using online interactive technologies to enhance cooperation of the educator and students during lessons [8], and to provide assessment and constructive feedback in the process of foreign language competence development [9] has been comprehensively described. 
Even though an impressive amount of research has been conducted with regard to the characteristics of different forms and purposes of student assessment, and its impact on student progress and outcomes by P. Black and D. Wiliam, A. Cullinane [10], M. Heritage, R.L. Linn, L. Voinea [11], G. Wiggins and others, as well as the specifics of foreign language testing and assessment, and foreign language teacher assessment literacy by A. Hasselgreen et al., K. Vogt and D. Tsagari, C. Coombe et al. and others, the issue of using game-based online resources as a means of student assessment and effective feedback provision at FL lessons seems insufficiently studied.

Therefore, the purpose of this article is to describe the mechanics of some digital game-based tools and analyse their properties in terms of their effectiveness as means of student formative assessment and their ability to maximize teacher feedback quality in order to develop students' foreign language competence with regard to the requirements devised for traditional formative assessment.

\section{RESEARCH METHODS}

A variety of theoretical methods have been applied in this research. Critical analysis of scholarly papers and sources of applied nature as well as generalization of the findings have been used to uncover the issues that require further exploration. The empirical method of studying students' works (the results of their participating in online gamified activities) has been undertaken in order to provide a comprehensive description of the benefits of the chosen digital interactive tools as effective means for a constructive feedback as part of formative assessment and evaluation of student performance at foreign language lessons.

Based on our own experience of integrating elements of gamification into the lessons of English for Specific Purposes for undergraduate students, a number of online game-based learning platforms, particularly Kahoot!, Wordwall and Mentimeter, have been selected for analysis in this research, as these tools can be incorporated in online lessons using video conferencing solutions, such as Zoom, Skype or Google Meet. The requirements to traditional formative assessment served as the criteria for evaluation of the effectiveness and reliability of the above tools as means of student formative assessment at foreign language lessons.

\section{FINDINGS}

\subsection{Gamification and game-based learning}

For the purposes of this research it seems essential to make a distinction between the concepts of gamification and game-based learning. Although the aims behind these two concepts appear to be the same - to boost learner engagement and motivation, in scholarly literature they are described as possessing different properties.

Gamification is an application of elements from game design and principles and theories which drive gameplay to other environments "to motivate players to engage in a task they otherwise would not find attractive" [2, p. 259]. The idea is to "use various proven elements of games to motivate greater involvement" [9, p. 3]. Gamification penetrates all spheres of our life ranging from problem solving and employees' engagement in the workplace training to building learner engagement in formal education. Gamification in learning, thus, may be defined as the use of game practices and game techniques for educational purposes [12, p. 347]. O. Tkachenko [5, p. 307] differentiates between gamification in a broader sense, which implies the use of both games and game practices in education, and gamification in a narrower sense as the application of game techniques and mechanics to education. 
Game-based learning applies conventional and digital games to teach knowledge and skills or to reinforce the existing knowledge and skills. In other words, game-based learning is defined as "learning through computer games designed purely for educational purposes" [3, p. 2770]. This definition of game-based learning seems to correlate with gamification in broader sense in O. Tkachenko's terms. However, any digital tool where certain game elements and a fun factor are integrated "to solve a given problem within an enjoyable learning environment" $[14$, p. 221] may be regarded through the prism of gamification approach to teaching. In this paper, digital educational resources that possess game mechanics are considered gamification tools applicable for formative assessment and teacher feedback. As students usually tend to find conventional non-motivational activities disengaging, integrating learning tools with the elements which are intrinsic in games and play into teaching and learning presents a number of advantages.

One of the major benefits of gamification and particularly gamification in education highlighted by the researchers is its capability to motivate. Any routine classroom activity, which, if conducted in a conventional way, may demotivate learners and cause them to lose interest in the subject, tends to increase student engagement and improve learning outcomes with the help of some gamification tool [2], [3], [4], [14]. J. L. Plass et al. maintain that four types of engagement - cognitive engagement, affective engagement, behavioral engagement and sociocultural engagement - are triggered by gamification for learning [2, p. 260]. Cognitive engagement implies mental processing and metacognition. It is also associated with self-regulation, investment in learning, critical thinking and establishing connections with reality [3, p.2769]. Affective engagement involves emotional processing and regulation, it reveals itself in students' interest in the subject. As far as behavioral engagement is concerned, it is achieved by means of using gestures or asking players to perform certain actions or types of movements and results in "positive body language, attention, and confidence while initiating and completing learning activities" in class [ibid., p. 2769], while sociocultural engagement is supported by collaborative activities [2, p. 260].

Student engagement and motivation are achieved through specific game elements characteristic of any digital gamified tool. According to the study conducted by Bunchball Inc., a cloud-based software producer, in 2010, these elements include game mechanics and game dynamics $[15$, p. 2]. Game mechanics are various mechanisms and actions employed to "gamify" an activity [ibid., p. 2] in order to stimulate specific emotions in the player. Game dynamics is the result of these emotions and motivations. The correlation of the abovementioned elements is presented in Figure 1.
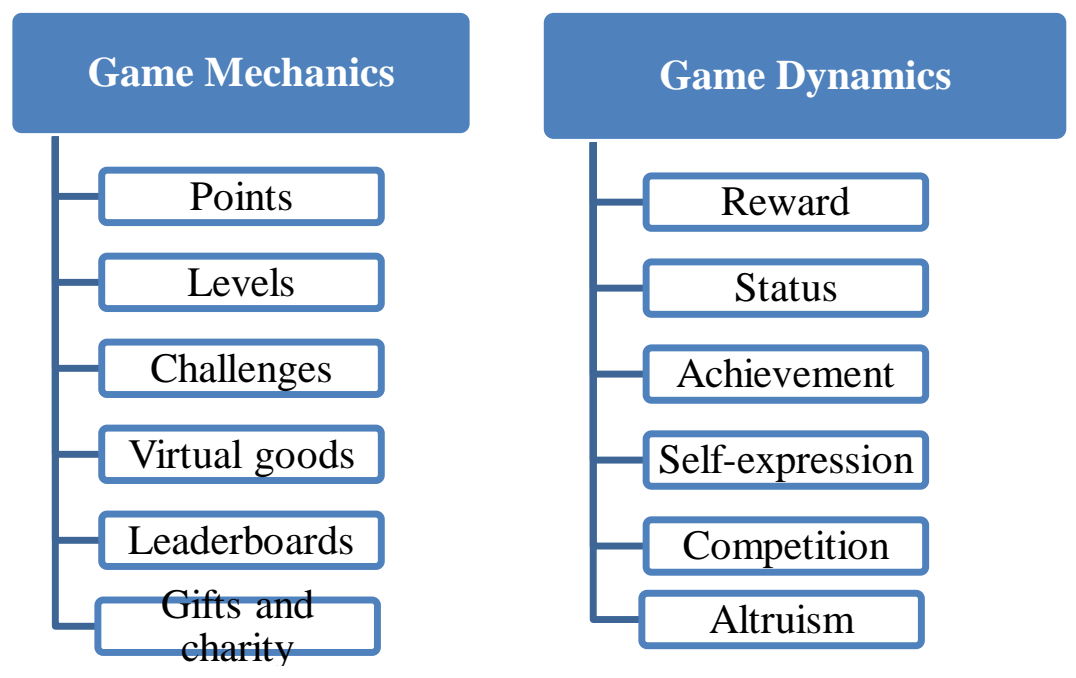

Figure 1. Correlation of game elements in a gamified resource 
Game elements displayed in Figure 1 can be found in any digital game or a gamified tool. However, we offer a modified list of game elements which are characteristic of educational gamified tools and resources (Fig. 2).
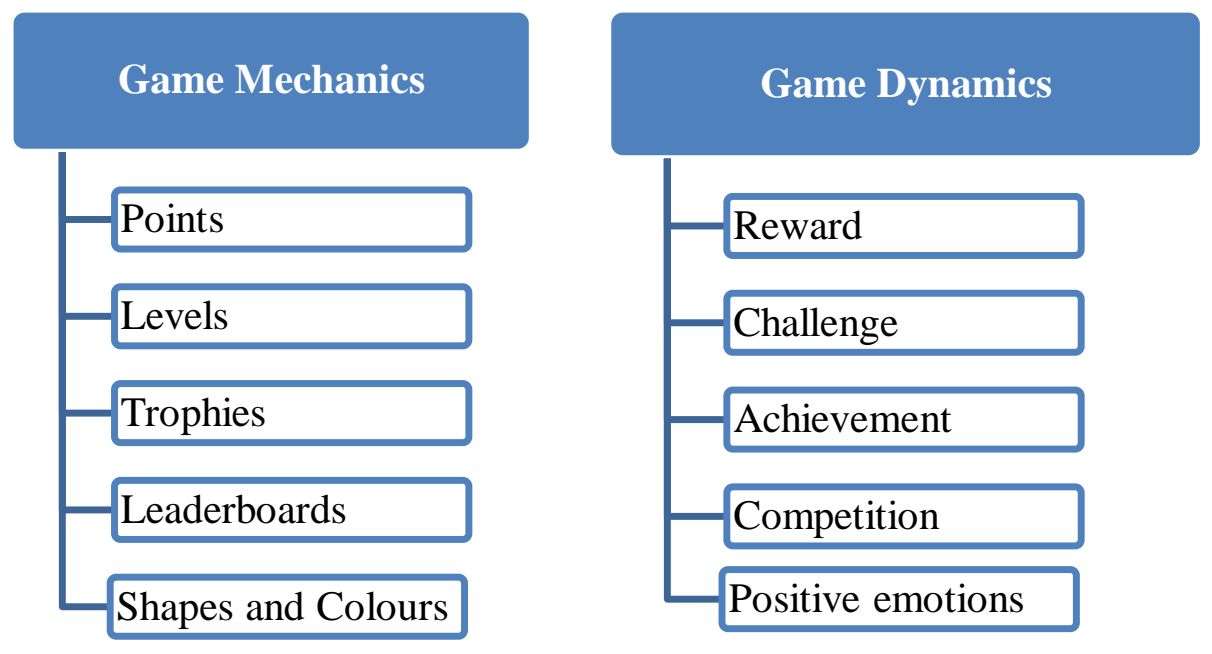

Figure 2. Correlation of game elements in educational gamified tools

Exciting and amusing content of gamified resources together with the system of rewards, which is designed to trigger the sense of achievement and status, and vast opportunities for competition with other students for high-scores and leaderboard rankings appear to reinforce motivation and students' interest in studying. In all three online tools analysed in this research, points are awarded to players for correct answers. Each student can see their individual result or score as well as the ranking immediately after the activity is over. Students can see whether their response is correct as soon as they give it. In case of the wrong response, the correct answer is also provided. In Kahoot!, the participants' rank, correct answers in percent, a number of unanswered questions and the final score of each player are saved to the account of the teacher who hosted a specific kahoot, and can be accessed in Reports in the toolbar. In Wordwall, the time of the game completion is shown to each player if the timer has been set by the hosting teacher. In this online resource, results by student and results by question are saved to the teacher's account in My Results in the toolbar. In Mentimeter, students' responses together with the date of the session and other useful statistics can be exported directly to an Excel spreadsheet on the teacher's computer with the help of the Download results button. Reports on student performance results in Kahoot! can also be downloaded in a spreadsheet to be shared with other educators.

Both in Kahoot! and Wordwall leveling up is available to the teacher due to the timer function. The instructor can set the timer for a different time limit every time the game is played with or without the countdown.

Kahoot! and Wordwall are equipped with the leaderboard function, which may be activated in the settings by the hosting teacher. Leaderboard displays the achievements of each participant in terms of scores and ratings, and allows students to gauge their performance against other players. At the end of a game in Kahoot! the so-called "podium" appears showing the nicks or names of the first three top players followed by fourth and fifth places, their scores and the number of correct answers.

In Kahoot! and Wordwall, bright colours and various shapes are available for task creation; musical effects accompany both the process of playing and displaying the results. Mentimeter also allows a choice of multicolor graphics for the background of tasks as well as for responses and results. 
However, some researchers of the impact of gamification on education point out that a simple use of points and badges to reward achievement in gamified tools may stimulate interest in the short-term, but eventually result in students' poor learning outcomes and underachievement.

According to M. Robertson, one of the drawbacks lies in the oversimplified attitude of game developers to the mechanism of awarding points and badges or the so-called "pointification" [16]. Receiving points as a kind of reward for achievement triggers external motivation, which replaces internal motivation, reducing it in the long-term period [17].

Another issue which is a subject of criticism is the deteriorating effect of competition on cooperation in tasks intended for cooperative setting. The issue here is that the function of such an essential element of game mechanics as "leaderboard" is to display the user's ranking as compared to the others, which may influence some of the players causing anger or jealousy and, thus, undermining motivation to participate in an activity where collaboration of the players is required [9, p. 44].

Despite the criticism of certain elements of gamification, the potential of digital gamified resources for teaching and learning to provide prompt feedback to students and actionable insight for the instructor is highlighted in the scholarly literature. The success of gamification is based on "creating motivation by using feedback to give the user a clear sense of the goals and the means for achieving those goals" [17]. In addition "to setting clear objectives, a clear progression and clear evaluation criteria, games provide continuous feedback and a response to the individual's progress" [ibid.].

\subsection{Gamified Tools for Formative Assessment}

The ongoing process of interaction between teachers and students during lessons which aims to provide feedback in order to adjust instruction to students' needs and achievements is referred to in pedagogy as formative assessment or assessment for learning. The assessment is considered formative if it "improves teachers" instructional planning" [18] and is beneficial to students "in taking ownership of their learning" [10, p. 1]. In contrast to summative assessment or assessment of learning, which is designed to measure what students have learned at the end of the unit/course and is used to gauge students' performance against required standards, formative assessment is interactive and employs a variety of means in terms of scope and methodology. Formative assessment is closely linked to feedback through which the information about students' progress is brought back to them [11, p. 10]. Through feedback received from the teacher students can become active participants of the learning process, monitor their performance and progress.

The research conducted by the Center for Educational Research and Innovation of OECD established the following key elements of formative assessment $[19$, p. 6]:

1. Establishment of a classroom culture that encourages interaction and the use of assessment tools;

2. Establishment of learning goals, and tracking of individual student progress toward those goals;

3. Use of varied instruction methods to meet diverse student needs;

4. Use of varied approaches to assessing student understanding;

5. Feedback on student performance and adaptation of instruction to meet identified needs;

6. Active involvement of students in the learning process.

In this research we would like to trace how the key requirements to student formative assessment can be met with the help of a selection of gamified tools (Table 1). 
Table 1

Realization of Formative Assessment Characteristics in Assorted Gamified Tools

\begin{tabular}{|l|c|c|c|}
\hline \multicolumn{1}{|c|}{ Elements of Formative Assessment } & \multicolumn{3}{c|}{ Gamified Tools } \\
\cline { 2 - 4 } & Kahoot! & Wordwall & Mentimeter \\
\hline $\begin{array}{l}\text { 1. Establishment of classroom culture that } \\
\text { encourages interaction and the use of assessment } \\
\text { tools; }\end{array}$ & + & + & + \\
\hline $\begin{array}{l}\text { 2. Establishment of learning goals, and tracking of } \\
\text { individual student progress toward those goals; }\end{array}$ & + & + & + \\
\hline $\begin{array}{l}\text { 3. Use of varied instruction methods to meet } \\
\text { diverse student needs; }\end{array}$ & + & + & + \\
\hline $\begin{array}{l}\text { 4. Use of varied approaches to assessing student } \\
\text { understanding; }\end{array}$ & + & + & + \\
\hline $\begin{array}{l}\text { 5. Feedback on student performance and } \\
\text { adaptation of instruction to meet identified needs; }\end{array}$ & + & + & + \\
\hline $\begin{array}{l}\text { 6. Active involvement of students in the learning } \\
\text { process. }\end{array}$ & + & + & + \\
\hline
\end{tabular}

Element 1, which seems to be the central requirement to formative assessment, means integration of formative assessment into the teaching process, exposing students to its various forms and tools and encouraging them "to feel safe to take risks and make mistakes in the classroom" $[19$, p. 7], laying the emphasis on task achievement rather than on competing with peers. In this respect, all the selected gamification tools appear to be capable of fulfilling these requirements. All three resources can be integrated in remote or hybrid learning. Firstly, they can be incorporated in online lessons via Zoom, Skype or Google Meet. To use these tools during a synchronous class as part of distance learning, the instructor can create their own activity and host a live game by sharing their screen using a video conferencing platform or send a link to the students. In addition, both Wordwall and Mentimeter allow for the slides/screenshots of the activities to be downloaded in PDF so they could be printed out and used as handouts during a conventional lesson.

Provided the clear learning goals are set, the use of activities designed on the basis of gamified tools as means of formative assessment may facilitate tracking individual students' progress both for the teacher and for students themselves, which correlates with Element 2 in Table 1. An important issue here is that gamified tasks are performed independently and the result is displayed to each student individually, revealing their individual progress. It can also diminish the risk of students' comparing their results with those of their peers, which may impair motivation, but stimulate them to focus on their own achievements. The leaderboard function as well as the timer function can be adjusted to students' needs and the purposes of the activity. Thus, the leaderboard in Wordwall may be disabled if necessary, and the timer can be reset both in Wordwall and Kahoot! to suit every new group of students or each new customized activity.

Elements 3 and 4 imply that the choice of activities as well as assessment methods must be based on the assumption of individual differences and diverse needs of students. Quizzes created with Wordwall, Kahoot! and Mentimeter can be employed during FL lessons for a variety of purposes: vocabulary practice to consolidate the material and to reinforce learning; formative assessment to assess the knowledge of the syllabus vocabulary and grammar; listening and reading comprehension; revision to make sure students retained the key concepts of the course. Wordwall may be a representative example of a variety of tasks, ranging from matching and sorting activities to word search and crossword puzzles, which can be created 
with the help of a gamified online platform to serve the purposes of a FL course in terms of grammar and vocabulary practice and assessment, as displayed in Figure 3.

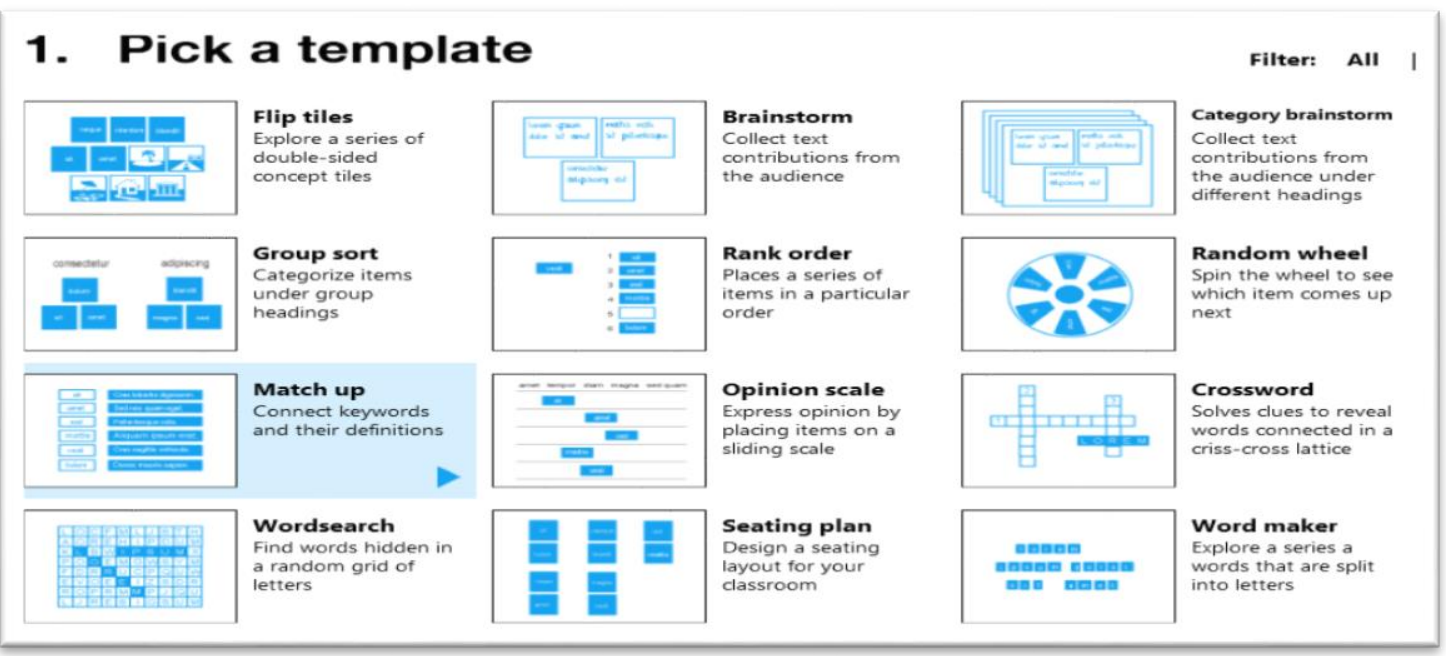

Figure 3. Templates available in Wordwall

Game mechanics of online tools analysed in this paper allows employing individual approach to student assessment with the help of the adjustable timer function, which can be turned off for student-paced activities and activities set for homework. As far as points and trophies are concerned, they can be removed for lower-stake tasks for students to focus on their knowledge and skills rather than on achievements. Besides, within the set time-frame students may be given an opportunity to do the task one more time before it is submitted for evaluation. This may be beneficial for lower achieving students, as the results of such tasks, when used formatively, do not impact negatively on the students' self-esteem, still giving a useful insight into students' current progress and tips for further learning.

Detailed information on students' performance in activities, which is provided in gamified online platforms such as Wordwall, Kahoot! and Mentimeter, such as the number of correct and incorrect answers by question, results by student, most challenging questions or unanswered questions, fastest-performing students, average performance time, enables the teacher to draw valuable conclusions to be used for feedback. As illustrated by the report on correct/incorrect answers by student to question 7 of the Kahoot! quiz on the target vocabulary for the topic "Criminal Law", which we used in our ESP lessons for undergraduate students, the student nicknamed Alien gave the wrong answer to this question, though it did not appear challenging for the rest of the group (see Fig. 4).

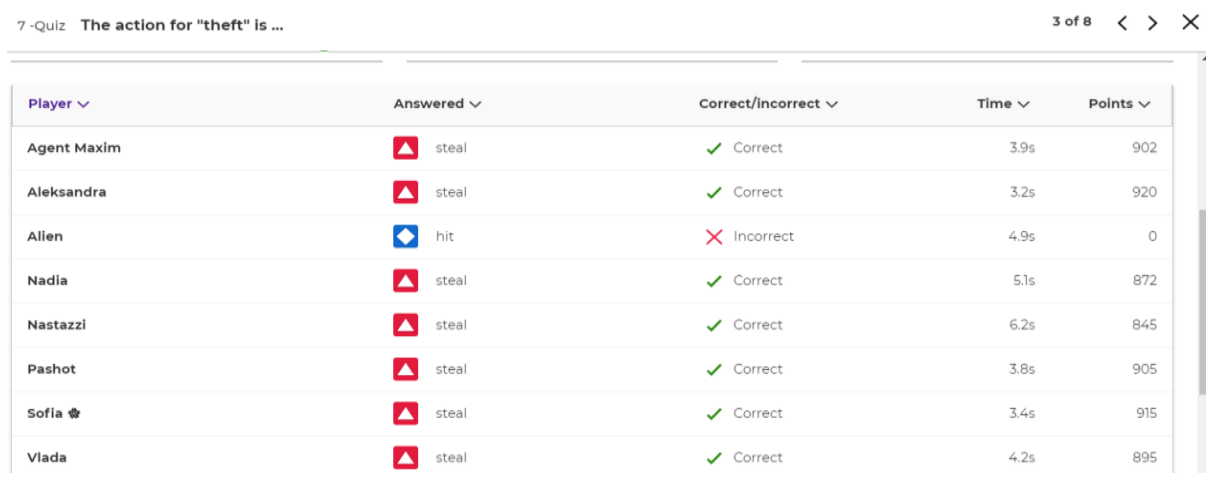

Figure 4. Answered/unanswered Questions by Student Report in a Kahoot! quiz 
The analysis of this student's performance in the quiz (Fig. 5) shows inter alia that it took her longer than average to answer the other questions in the activity, which is crucial for preparing specific recommendations as teacher's feedback.

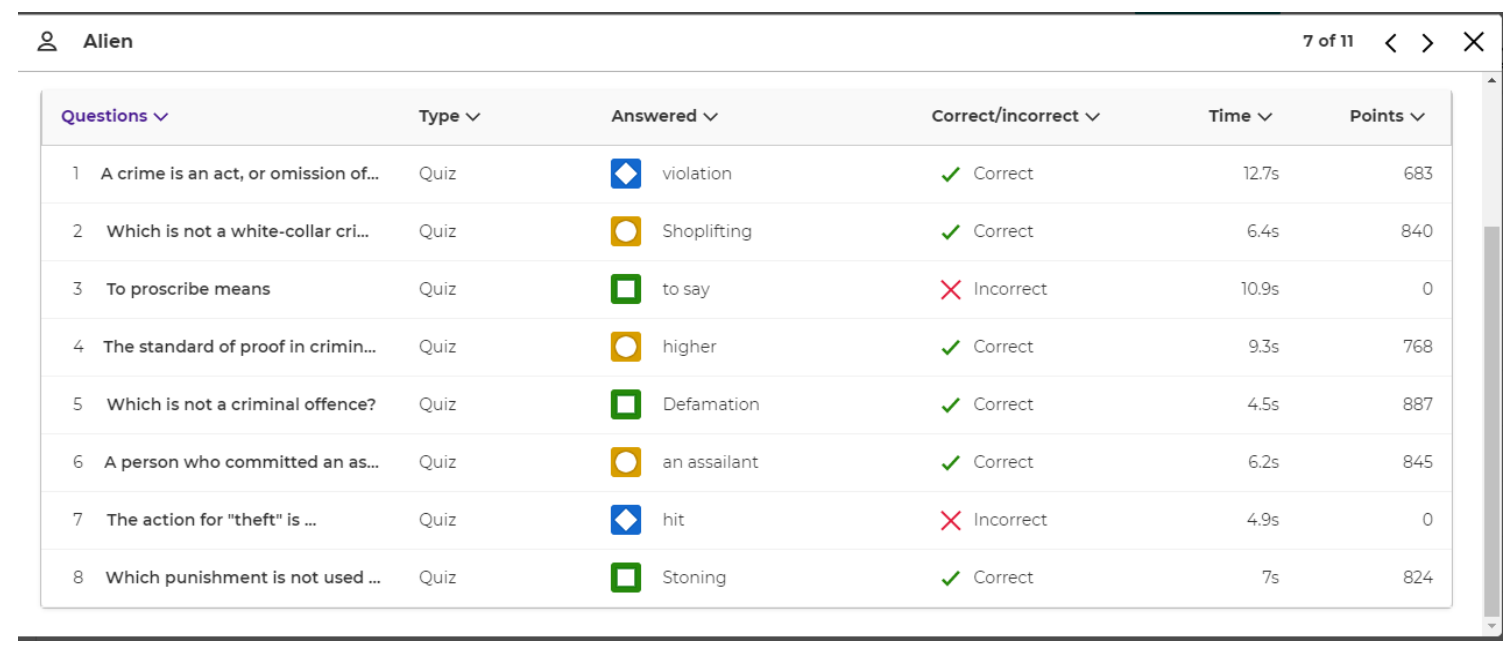

Figure 5. Individual Student Performance Report in a Kahoot! quiz

These data provide the FL teacher with comprehensive information not only on their students' progress, but also on the quality of the task, its methodological value; this information may draw the teacher's attention to the aspects which are clear to the students and which, on the contrary, cause difficulty, thus helping educators adjust their teaching methods to the identified needs of students (Element 5).

Clear-cut understanding of students' needs and achievements, which FL teachers who design their own customized activities with the help of gamified online tools are enabled to build analyzing the reports provided by such commands as Reports in Kahoot!, My Results in Wordwall or the Download results button in Mentimeter, is likely to result in a more effective feedback, whose aim is to assist students in building their own strategies to achieve learning goals (Element 6). In addition, possibilities for self-assessment offered by gamified activities boost student involvement in the learning process, equipping students with awareness of the quality of their performance and building confidence in managing and controlling their learning a foreign language.

\section{CONCLUSIONS AND PROSPECTS FOR FURTHER RESEARCH}

Game-based learning is learning through computer games or any game-based tools with certain game elements which can be integrated into conventional or online teaching and learning to teach knowledge and skills in an enjoyable learning environment. These digital educational resources may be used in educational process for the purposes of formative assessment in order to monitor student progress and improve learning outcomes through effective teacher feedback.

It has been established that educational tools and resources possess specific elements of game mechanics, such as points, levels, trophies, leaderboards, shapes and colours, which trigger the following states and emotions: reward, challenge, achievement, competition, positive emotions, referred to as game dynamics. The abovementioned mechanisms of gamification appear to stimulate students' sense of achievement, interest in learning and motivation to progress. 
Interactive quizzes based on such online tools as Kahoot!, Wordwall or Mentimeter proved to be effective during FL lessons as means of formative assessment in higher education due to their ability to provide quick and objective feedback through gamified indicators of achievement and detailed reports on student progress, set meaningful targets and display ways for students to upgrade.

The research suggests that activities created with the help of Wordwall, Kahoot! and Mentimeter can be employed during FL lessons to practise vocabulary and grammar, to consolidate the material and reinforce learning, to assess the knowledge of the syllabus vocabulary and grammar, to check comprehension of texts, to revise for tests. They transform routine activities into challenging tasks, which encourage students' participation and perseverance in mastering a foreign language.

Thus, using elements of gamification for educational purposes can foster students' motivation for learning a foreign language, make FL lessons interactive and engaging for students and boost their feeling of community when they study remotely. Also, the use of digital gamified resources provides FL teachers with a variety of instruction tools and assessment techniques to meet individual student needs. Moreover, detailed reports on student performance in activities available to the hosting teacher offer useful data for analysis and facilitation of creating an effective teacher feedback aimed at developing students' foreign language competence.

While gamified online tools proved to be highly effective as possibilities for formative assessment at FL lessons in higher education institutions, still there is a need for further research. Further studies may be undertaken to address the impact of gamified tools on general student achievement in FL courses or to trace their effect for underachieving students. Also, it may be necessary to explore the impact of interactive online resources on students' progress in FL courses, based on age or gender.

\section{REFERENCES (TRANSLATED AND TRANSLITERATED)}

[1] D. Newman, "Top 6 Digital Transformation Trends in Education". [Online]. Available: https://www.forbes.com/sites/danielnewman/2017/07/18/top-6-digital-transformation-trends-ineducation/?sh=7497f3a02a9a. Accessed on: Sep.27, 2021. (in English)

[2] J. L. Plass, B. D. Homer, and C. K. Kinzer, "Foundations of Game-Based Learning". Educational Psychologist, no. 50(4), pp. 258-283, 2015, doi: 10.1080/00461520.2015.1122533. (in English)

[3] A. Khan, H. A. Farzana, and M. M. Malik, "Use of Digital Game Based Learning and Gamification in Secondary School Science: The Effect on Student Engagement, Learning and Gender Difference". Education and Information Technologies, no. 22(6), pp. 2768-2803, Nov. 2017, doi: 10.1007/s10639017-9622-1. [Online].

Available: https://www.researchgate.net/publication/318457365_Use_of_digital_game_based_learning_and_gamific ation_in_secondary_school_science_The_effect_on_student_engagement_learning_and_gender_differenc e. Accessed on: Sep.27, 2021. (in English)

[4] D. Yousef, S. Baadel, and R. Makad, "An Exploratory Study on the Impact of Game-based Learning on Student Engagement", in Int. Conf. on Web and Open Access to Learning (ICWOAL), 2014. [Online]. Available:

https://www.academia.edu/22170342/Exploratory_Study_on_the_Impact_of_Game_Based_Learning_on _Student_Engagement. Accessed on: Sep.27, 2021. (in English)

[5] O. Tkachenko, "Gamification of Education: Formal and Informal Space". Aktualni Pytannia Humanitarnykh Nauk, no. 11, pp. 303-309, 2015. [Online]. Available: http://dspu.edu.ua/hsci/wpcontent/uploads/2017/12/011-45.pdf. Accessed on: Sep.27, 2021. (in Ukrainian)

[6] O. Karabin, "Gamification in the Educational Process as Development of Younger Pupils". Pedahohika formuvannia tvorchoyi osobystosti u vyshchyi i zahalnoosvitnii shkolakh, no. 67 (1), pp. 44-47, 2019, doi: 10.32840/1992-5786.2019.67-1.9.

[Online].

Available: http://dspace.tnpu.edu.ua/bitstream/123456789/14039/1/Karabin_Gameification_educational.pdf. Accessed on: Sep.27, 2021. (in Ukrainian) 
[7] T. Vakaliuk, O. Osova and O. Chernysh, "Using Information and Communication Technologies for the Formation of Linguodidactic Competence of Future Foreign Language Teachers". Information Technologies and Learning Tools, vol. 82, no. 2, pp. 77-92, 2021. [Online]. Available: https://journal.iitta.gov.ua/index.php/itlt/article/view/3868. Accessed on: Sep.27, 2021. (in English)

[8] M. Hladun and M. Sablina, "Modern Online Instruments of Interactive Education as Technology of Cooperation". Open educational e-environment of modern University, no. 4, pp. 33-43, 2018. [Online]. Available: https://openedu.kubg.edu.ua/journal/index.php/openedu/article/view/125/170. Accessed on: Sep.27, 2021. (In Ukrainian)

[9] V. Šilonová et al., "Use of Digital Technologies in Students' Distance Pedagogical Assessment at Higher Educational Institutions". Information Technologies and Learning Tools, vol. 82, no. 2, pp. 243-265, 2021. [Online]. Available: https://journal.iitta.gov.ua/index.php/itlt/article/view/4365. Accessed on: Sep.27, 2021. (in Ukrainian)

[10] A. Cullinane, "Formative Assessment Classroom Techniques". Resource \& Research Guides, vol. 2, no. 13, pp. 1-4, 2011. (in English)

[11] L. Voinea, "Formative Assessment as Assessment for Learning Development". Journal of Pedagogy, vol. 1, no. LXVI, pp. 7 - $23, \quad 2018 . \quad$ [Online]. Available: https://www.researchgate.net/publication/326190241_. Accessed on: Sep.27, 2021. (in English)

[12] G. Christians, "The Origins and Future of Gamification”, Senior theses, Honors College, Univ. of South Carolina, Columbia, USA, 2018. [Online]. Available: https://scholarcommons.sc.edu/cgi/viewcontent.cgi?article=1255\&context=senior_theses. Accessed on: Sep.27, 2021. (in English)

[13] J. Simoes, R. D. Redondo and A. F. Vilas, "A Social Gamification Framework for a K-6 Learning Platform". Computers in Human Behaviour, no. 29, pp. 345-353, 2013. [Online]. Available: https://www.computacional.com.br/files/Gerais/SIMOES\%20$\% 20 \mathrm{~A} \% 20$ social $\% 20$ gamification $\% 20$ framework $\% 20$ for $\% 20 \mathrm{a} \% 20 \mathrm{~K}-6 \% 20$ learning $\% 20$ platform.pdf. Accessed on: Sep.27, 2021. (in English)

[14] F. L. Khaleel, N. S. Ashaari, T. Wook and A. Ismail, "User-Enjoyable Learning Environment Based on Gamification Elements", in Int. Conf. on Computer, Communication, and Control Technology, 2015. [Online]. Available: Khaleel/publication/304627718_Userhttps://www.researchgate.net/profile/Firas-Laythenjoyable_learning_environment_based_on_Gamification_elements/links/5775d8fa08aeb9427e25c39a/U ser-enjoyable-learning-environment-based-on-Gamification-elements.pdf. Accessed on: Sep.27, 2021. (in English)

[15] "Gamification 101: An Introduction to the Use of Game Dynamics to Influence Behavior", Bunchball, White Paper, Redwood City, Cal., USA, Oct. 2010. [Online]. Available: http://jndglobal.com/wpcontent/uploads/2011/05/gamification1011.pdf. Accessed on: Sep.27, 2021. (in English)

[16] M. Robertson, “Can't Play, Won’t Play”. [Online]. Available: https://kotaku.com/cant-play-wont-play5686393. Accessed on: Sep.27, 2021. (in English)

[17] S. Ejsing-Duun and H. M. Skovbjerg, "Gamification of a Higher Education Course: What's the Fun in That?", in 8th European Conf. on Game Based Learning - ECGBL, 2014. [Online]. Available: https://www.researchgate.net/publication/280095411_Gamification_of_a_higher_education_course_What 's_the_fun_in that. Accessed on: Sep.27, 2021. (in English)

[18] M. Heritage, "Formative Assessment and Next-Generation Assessment Systems: Are We Losing an Opportunity?", the Council of Chief State School Officers, Washington, DC, USA, Sep. 2010. [Online]. Available: https://files.eric.ed.gov/fulltext/ED543063.pdf. Accessed on: Sep.27, 2021. (in English)

[19] "Assessment for Learning. Formative Assessmsnt", in OECD/CERI Int. Conf. "Learning in the 21st Century: Research, Innovation and Policy”, pp. 1-24, 2008. [Online]. Available: https://www.oecd.org/site/educeri21st/40600533.pdf. Accessed on: Sep.27, 2021. (in English)

Text of the article was accepted by Editorial Team 28.09.2021

\title{
ЗАСТОСУВАННЯ ЦИФРОВИХ ІГРОВИХ ІНСТРУМЕНТІВ ДЛЯ ФОРМУВАЛЬНОГО ОЦІНЮВАННЯ НА ЗАНЯТТЯХ 3 ІНОЗЕМНОЇ МОВИ
}

\author{
Жигадло Олена Юріївна \\ кандидат філологічних наук, доцентка кафедри іноземних мов Навчально-наукового інституту права, \\ Київський національний університет імені Тараса Шевченка, м. Київ, Україна \\ ORCID ID 0000-0002-1605-7242 \\ olena.zhygadlo@gmail.com
}


Анотація. У статті досліджено можливості ігрових онлайн-ресурсів для застосування їх у якості засобів формувального оцінювання під час занять 3 іноземної мови у вищих навчальних закладах. Автор вважає характерним для ігрового підходу до навчання використання будь-яких ігрових інструментів з певними елементами гри, які можуть бути інтегровані в традиційне або онлайн навчання,. Дослідження встановило основні елементи освітніх інструментів гейміфікації, серед яких бали, рівні, трофеї, таблиці лідерів, форми та кольори. Ці елементи ігрової механіки здатні викликати такі почуття та емоції, як винагорода, виклик, досягнення, змагання та позитивні емоції. Ряд теоретичних та емпіричних методів дослідження застосовано для аналізу та встановлення переваг цифрових інтерактивних засобів як ефективного засобу формувального оцінювання успішності студентів в оволодінні іноземною мовою та безцінного джерела конструктивного зворотного зв'язку для розвитку їх іншомовної компетентності. Для аналізу були обрані три навчальні гейміфіковані платформи: Kahoot !, Wordwall та Mentimeter. Будучи сумісними 3 популярними сервісами для відеоконференцій, ці інструменти $є$ простими в освоєнні та відповідають цілям та завданням занять з іноземної мови. Автор стверджує, що завдання, розроблені за допомогою Wordwall, Kahoot! та Mentimeter, можна використовувати під час занять з іноземної мови для відпрацювання словникового запасу та граматики, закріплення та повторення пройденого матеріалу, оцінювання знань програмної лексики та граматики, перевірки розуміння текстів, а також для підготовки до контрольних робіт. Аналіз ігрової механіки доводить, що електронні ігрові інструменти сприяють засвоєнню знань i набуттю навичок, впливаючи на мотиваційну сферу студентів, створюючи приємне навчальне середовище та забезпечуючи оперативний зворотний зв'язок. Ще однією важливою перевагою цифрових гейміфікованих інструментів $є$ їх здатність надавати викладачеві різноманітні техніки навчання та методи оцінювання для задоволення індивідуальних потреб студентів. Детальні звіти про успішність студентів, доступні на панелі інструментів цих платформ, містять корисні дані для аналізу та створення ефективного зворотного зв'язку, спрямованого на розвиток їх іншомовної компетентності.

Ключові слова: гейміфікація навчання; зворотний зв'язок; внутрішня i зовнішня мотивація; іншомовна компетентність; інструменти дистанційного навчання.

\section{(cc) BY-NC-SA}

This work is licensed under Creative Commons Attribution-NonCommercial-ShareAlike 4.0 International License. 